MANUSCRIPT

Susanne Gillmayr-Bucher. A Hero Ensnared in Otherness? Literary Images of Samson.

Published in:

Erik Eynikel and Tobias Nicklas (ed.). Samson: Hero or Fool? The Many Faces of Samson (TBN 17). Leiden, Boston: Brill 2014, pp. 33- 51. 


\section{A HERO ENSNARED IN OTHERNESS? \\ LITERARY IMAGES OF SAMSON}

The fact that Samson is different has always been noticed when dealing with the stories in Judg 13-16 (Kegler 1985, 114; Greenstein 1981, 239-243). In more than one way he does not fit into the established text-worlds of the book of Judges. Well known and accepted social, ethnical as well as religious boundaries are transgressed and collapse in the course of the story (Camp 2000, 134). Thus the expectations the story evokes in its readers are not fulfilled, quite contrary, everything appears to be turned upside down. Based on contrasts and boundaries (Exum 1993, 72-77) the story sets into motion once Samson starts to transgress them. Samson is portrayed as 'the other' from different perspectives, nevertheless his otherness is neither clearly defined nor are the relations between the different aspects of his otherness evident. Samson appears to be entangled in his otherness.

While the biblical text shows Samson's otherness as a multilayered picture, the literary adaptations of this story in the 20th century reduce this complexity and portray Samson as a more coherent other transferring Samson into the cultural boundaries of their own times.

\section{Samson, the Other Hero, in the Biblical Text}

In the biblical story otherness is not restricted to specific figures or groups of figures. Rather all relationships are affected. On a national level it concerns the relations between the Israelites and the Philistines, as well as the people's relation to their deity. On a personal level the relations include Samson, his parents, his wife in Timnah and Delilah. Nonetheless, the borders between national and personal level are blurred and more than once an episode includes national as well as personal aspects. Furthermore the world of the figures is neither congruent with one another nor with the world of the narrating voice. ${ }^{1}$ This once more increases the possible perspectives on otherness.

\footnotetext{
${ }^{1}$ Cf. Gillmayr-Bucher, Erzählte Welten, 183-186.
} 
Israelites-Philistines

In contrast to preceding stories of the judges Deborah, Gideon and Jephthah, the relationship between the Israelites and the Philistines is ambivalent in Judg 13-16. According to the narrative frame that links all stories, the Philistines are introduced as Israel's enemies and oppressors (13:1). Twice, this role becomes a subject of a discussion. Samson's parents offer the first explicit negative view on the Philistines. In their rejection of Samson's foreign wife, they call the Philistines 'uncircumcised' (14:3). This distinctive detail marks the Philistines as 'the other' and thus adds a pejorative valuation from the parent's point of view. Later, when the men of Judah turn against Samson (15:11) it becomes obvious that they regard the Philistine presence as an occupation to be endured. Again the Philistines are clearly marked as 'the other'.

This explicit differentiation forms the background of the story and is emphasised when Samson challenges it. While the Israelites try to keep their distance from the Philistines, Samson frequently looks for encounters. Contrary to his parents and his fellow countrymen, Samson does not consider the Philistines as enemies per se nor does he show them the respect an occupying force might demand. Samson does not share the common conception of 'otherness'; 2 he rather acts according to his own standards. Hence Samson feels free to take a wife from the Philistines, he considers 'right in his eyes' (14:3) and as his rightful property (14:18; 15:1). Additionally, his hostility towards the Philistines is not portrayed as an ethnical conflict; Samson rather acts on the spur of the moment and for private motives. His fighting with the Philistines resembles personal quarrels, the lost riddle (14:18-19), the murder of his wife and father in law $(15: 6)$ or the ambush in Gaza (16:2-3). When he reflects upon his actions, Samson explains his aggression as a reaction to sustained damage, but not as hostility towards the Philistines as Israel's enemies $(15: 3,7)$. Even his last vengeance is shown as a personal matter (16:28). Samson refuses to accept a given otherness between Israelites and Philistines. ${ }^{3}$ Accordingly, otherness is not primarily a national concern but a personal one.

The contrast between the traditional ethnical difference and Samson's ignorance thereof is further increased by Samson's mission. Samson is chosen to 'begin to save' Israel from the hand of the Philistines' (13:5). In

\footnotetext{
${ }^{2}$ The way Samson acts shows that he considers the Philistines as neighbours he inter-acts with.

${ }^{3}$ Nevertheless, the narrator interprets Samson's last success as a national achievement (16:30).
} 
this foreordination the Philistines are clearly marked as 'the others' and it is Samson's task to enforce this separation. ${ }^{4}$

The Philistines' view on Israel is not expressed in general, the biblical texts rather focus on the their attitude towards Samson. It is not ethnic differences but Samson's hostile acts that cause their hostility. First they treat Samson as an equal (Weitzman 2002, 165, 169) and even after Samson torched their fields the Philistines refer to him as 'son in law of the Timnite' (15:6) and punish his father in law for depriving Samson of his wife. From the Philistines' point of view Samson's wife still belongs to Samson (14:15-16). Samson is not marked as an Israelite and just might be one of their own. Although the conflict gains momentum it continues on a personal level. Only after Samson's repeated aggressive and hostile actions the Philistines treat him like an enemy. In the last part of the story (16:430) Samson finally becomes 'the other', the enemy par excellence (16:2324).

\section{Women's View on Samson}

In contrast to the Philistines as a people, the two women, Samson's wife in Timnah and Delilah, ${ }^{5}$ are portrayed as antagonists $(14: 15-17 ; 16: 5-21)$. Their role is restricted to their betrayal of Samson's secrets. Instructed by a group of Philistines the women prepare the way for the men's schemes. Hence, they are shown as 'the other' almost from the beginning of their appearance in the story. The narrator even introduces the woman in Timnah as a chosen adversary by YHWH (14:4). While the woman in Timnah is threatened by her fellow countrymen ${ }^{6}$ and subsequently caves in, Delilah accepts an offer from Philistine sovereigns. ${ }^{7}$ Although Delilah's nationality

\footnotetext{
${ }^{4}$ However, this point of view is not common knowledge in the story. It belongs to the intention of the messenger and the knowledge of Samson's mother as well as the narrating voice. Outside the communication between the messenger and Manoach's wife (13:3-5) this topic is only picked up by the narrating voice as it comments the events for the readers (14:4). At the end of the story Samson's mission is once more alluded to as the narrating voice (16:30e-f) summarises Samson's last achievement. Although he did not intentionally follow his mission his destiny came true nevertheless. The narrating voice shows a genuine concern to verify the predetermination.

${ }^{5}$ Although the story does not tell whether Delilah is a Philistine or Israelite, she solely acts as an ally of the Philistines.

${ }^{6}$ The ethnical relationship is emphasised as the woman in Timnah refers to them (14:16) as 'my people' (בני עמי).

${ }^{7}$ Delilah is the only antagonist who is given a name. She is, however, not the ethnical other but she accepts the role of an opponent.
} 
remains a secret her cooperation with the Philistines alludes to the image of the foreign, seductive and thus deadly woman (Exum 1996, 188). Both women pursue a similar strategy. They approach Samson quite directly with their questions. When their request is rejected they appeal to his love and demand that he trusts in them. ${ }^{8}$ Thus they exploit Samson's inability to see through the whole scheme. Put on stage as 'the other' ${ }^{\prime}$ the women's own attitude towards Samson is not revealed. The focus lies on their cleverness to outwit Samson and to deprive him of his advantage of superior knowledge. At the same time the women's action exposes Samson as the only one who does not know what is going on. Samson does not see the 'otherness'.

\section{Samson and His People}

Throughout the story Samson is shown as a hero who does not belong. His otherness is most clearly marked in comparison to his own people. Samson distances himself with everything he does. The story of Samson's birth already singles him out and suggests that he will gain an exceptional position within Israel, yet the anticipations of this opening are not fulfilled.

The first sign that Samson will not grow up to be a leader who overpowers the oppressors in a military conflict is given in the summary of רוח Samson's adolescence (13:25). The narrating voice points out that the יהוה troubles Samson and makes him restless between Zorah and Eshtaol. Thus he is already driven to the borderlands but without a clear mission.

The conflict with his own people steps forward as he discusses marrying a Philistine woman with his parents. Their point of view is well defined. They keep a strict distance to the Philistines and want to preserve their identity as an identity of a people. Consequently they regard Samson's marriage to a Philistine woman as trespassing (14:3). This episode starts Samson's frequent crossing of the borders.

\footnotetext{
${ }^{8}$ The biblical concept of love (אהב) includes desire and that leads to adequate actions.

To love something or someone is to desire something/someone and to act accordingly in order to obtain the desired object. Usually there are actions that prove this love. Only Judg 14 and 16 does a woman request a sign of love. Nonetheless, love does not include a reciprocal relationship and it is also used to express emotions in the context of rape (Gen 34, 2 Sam 13). Thus the biblical concept of love proves different from our modern romantic idea of love (cf. van Wolde 2008, 19).

${ }^{9}$ The suspense of these episodes is built up by the difference in the knowledge of the readers and the figures in the story. While the readers and the Philistines are aware of the women as Samson's opponents, Samson himself lacks this knowledge.
} 
The attitude of the men of Judah towards Samson further emphasises his otherness (15:9-13). From their point of view Samson is endangering their way of life because he does not obey the rules of the Philistines, who rule the land. Samson is not a guarantor of Israel's identity and well-being, quite the contrary, he hazards Israel's security. On the one hand, he causes retaliatory actions from the enemies and, on the other hand, he threatens to blur the distinction between his own people and the Philistines. In that sense Samson is the other Israelite.

Samson's uniqueness is also emphasised by his explicit masculine attitudes (cf. Clines 1995). He is aggressive, extraordinarily strong and successful in his fights. Furthermore he claims the right to take vengeance and thus to re-establish his honour. These attitudes mark him as an exemplary man. But there are flaws that upset this image. Samson lacks civilisation, he resembles the untamed outsider that is feared but not accepted. ${ }^{10}$ This image is continued in the description of Samson's attraction to women.

Three times he chooses a woman he desires, but he only perceives them according to his own wishes. Subsequently, the woman in Timnah as well as Delilah become a fatal attraction. Samson's masculinity ends, once his hair is cut (16:19), he is humbled (ענה) ${ }^{11}$ and bereaved of his eyesight, his strength and his dignity. But alone and far from women Samson's masculinity recovers and in his last act his untamed masculinity bursts out once more. Yet, only after his death it is safe enough to reunite Samson with his family (16:31). The narrating voice makes one further effort to reunify Samson with his people as it reinterprets Samson's aggressive acts as a struggle against the Philistines and in doing so includes Samson into the narrative framework $(15: 20 ; 16: 31)$.

Samson-God's Other Tool

In describing Samson's otherness it is essential to examine his relation with God. Although Samson acts independently, ignores advice and only twice contacts God, the narrating voice adds an image of Samson based on his relationship to God.

The foundation for this relationship lies in the birth story. The emphasis on the destiny of the child to be born arouses considerable expectations.

\footnotetext{
${ }^{10}$ Bynum shows a likeness between Samson, Herakles and Centaurs, all three are unfit for civilised life (Bynum 1990, 66-68).

${ }^{11}$ To humble (ענה) alludes to a fate usually women have to endure. They are humbled, raped, especially in war times. Metaphorical speech uses the verb to bereave someone of his dignity (cf. Camp 2000, 101).
} 
Born to be נזיר (13:5,7) Samson is dedicated to the deity and simultaneously isolated from the people. To strengthen this relation Samson is the only biblical figure who is a Nazirite all his life. ${ }^{12}$ The required reference to the uncut hair (13:5) will be the most obvious reference to Samson's otherness (cf. Amit 1999, 277). Despite this strong emphasis the consequences from Samson's being a Nazirite are hardly mentioned. ${ }^{13}$ While the motive of the Nazirite fades into the background in the episodes of Judg 14-15 it surfaces again in 16:4-30. In this last encounter with the Philistines Samson's secret, his special relation to his deity, is revealed. Now one sign of a Nazirite, the hair that is not cut, forms an almost magical link to Samson's strength and his relationship to God (16:17). ${ }^{14}$ The relation between Samson and his God is stressed further by the narrating voice noting several times that the רוח יהוה comes over Samson. ${ }^{15}$ Only at the end of the story, when Samson prepares for his last act, his prayer reveals that he knows about God as a cause for his strength (16:28). With the רוח יהוה Samson is further singled out from the rest of the Israelites. Although Samson does not fit into any given pattern, there is no explicit reproval for his behaviour from the deity (Exum 1983, 31). The רוח יהוה rather seems to support Samson and in this way adds to the aspect of otherness in his portrayal. YHWH is the only one who does not mark Samson as 'the other', nevertheless, he rather sets him up as 'the other'. ${ }^{16}$

\section{Samson the 'Other'}

Whichever point of view is taken, Samson does not belong and he does not meet the expectations raised in the text. The ambivalence of Samson

${ }^{12}$ While the messenger focuses on the beginning: 'a Nazirite to God from the womb'

(13:5) Manoach's wife also mentions the end: 'a Nazirite to God from the womb to the day of his death' (13:7). Unlike this special Nazirite status people usually commit themselves to living as a Nazirite only for a few years (cf. Jonker 1992, 54-55).

${ }^{13}$ Whether Samson's acts in Judg 14-15 are violations of the Nazirite regulations is disputed. The story itself does not contain any reference (cf. Exum 1983, 32).

${ }^{14}$ The motive that magic strength resides in the hair is well known from different folkstories (cf. Niditch 1990, 612-613).

${ }^{15}$ It forces entry into him צלח (14:6, 9; 15:14). 13:25 the verb פעם (pi.) is used. The basic meaning of the verb is to stamp, or pound. 'Samson is (...) a man in whom it pounds, like the clapper of a bell, a man driven by inward energy in a series of pulsating motions' (Alter 1990, 49).

${ }^{16}$ The רוח יהוה could be one attempt to include Samson in the tradition of Judges.

Although Samson does not dedicate himself to his deity, comments of the narrating voice let the readers assume that YHWH controls the events (Exum 1983, 37; Jonker 1992, 59).

Samson is used for the deity's own purpose (Camp 2000, 117; Bynum 1990, 61). Thus a con-sistend storyline is established. 
lies - at least partially-in the lack of his firm stand on 'otherness'. Samson is always in between. Nevertheless, there is one dominant point of view shared by the narrating voice, Samson's parents as well as the men of Judah: Samson does not grow up to be a good son, a judge and deliverer of Israel or a faithful Nazirite, nor does he live up to the expectations of a true male. In almost every relationship he appears as 'the other', the one who challenges the concept, and in this way he does not fit into any given differentiation. ${ }^{17}$

The figure of Samson and the stories of his deeds differ in many ways from the portrayal of the other judges. The focus lies on Samson's personal conflicts with the Philistines whereby he is shown as an extraordinarily strong but lone fighter who only can be overwhelmed by deceit. The national dimension of the conflict between the Israelites and Philistines only forms the background for Samson's personal strifes (cf. Exum 1990, 425). With the last of the judges, the role of 'God's tool for his people', the schema designed for a judge, collapses (cf. Exum 1990, 413).

Thus the main otherness the texts highlights, lies between Samson and his role as a judge. Samson is portrayed as a leader who is different from all preceding judges (Amit 1999, 276). This all together makes Samson the other' by Israelite standards as well as the other judge in the eyes of the readers.

As the exemplary other Samson challenges traditions and values. However, his portrayal offers no well defined 'other' that may safely remain 'the other'. Rather Samson disturbingly combines elements of 'self' and 'other' and in this way asks for a new perspective of seemingly well established concepts. ${ }^{18}$

\section{Samson in the 20th Century}

At the beginning of the 20th century German-language literature offers several works that pick up the story of Samson and reflect their own dis-

\footnotetext{
${ }^{17}$ Waldenfels defines the other, das Fremde 'als das, worauf wir antworten und unausweichlich zu antworten haben, als Aufforderung, Herausforderung, Anreiz, Anruf, Anspruch oder wie immer die Nuancen lauten mögen' (Waldenfels 1997, 109).

${ }^{18}$ Samson's portray clearly shows traits of Bakhtin's concept of a carneval king with the typical process of exaltation and degradation. Born as a promised child and endowed with enormous strength his fall is foreseeable from the beginning. Yet his death simultaneously is a moment of triumph and celebration and the beginning of Israel's liberation (cf. Bakhtin 1985, 138-140).
} 
turbing questions of traditional values, 'self' and 'other' in this story. In a society where shame and honour, duty and emotions still are antipodes and military conflicts between nations are a major concern in Europe, Samson can become an exemplary hero. In the literary adaptations Samson frequently turns into a hero who oscillates between reason and emotion, duty and selfishness. He lives his otherness and he agonises it.

After the Second World War Nelly Sachs, a Jewish poet, once again picks up the Samson story for her scenic play 'Simson fällt durch Jahrtausende'. As she continues the story into the present time, she does not only use the biblical story as a model but rather Samson's 'otherness' is continued and re-enacted in the 20th century. ${ }^{19}$

\subsection{A Man Without a People}

When the biblical story is transformed, the variety of perspectives is usually reduced and simplified. Furthermore, most literary adaptations opt for a polarity where 'the other' is more clearly defined. In accordance with the biblical story the aspects of otherness are unfolded in the relations between Samson and Delilah and between Samson and his God. This is further enhanced by a clear ethical, national-political and religious oppo-sition between Israelites and Philistines that forms the background of the story. Samson and Delilah overstep these borders with strong intentions. These may be warlike, deceitful or even loving purposes. Whatever the original motivation, most of the time the transgression turns into a romantic love story.

Samson also is shown as a man with a mission. His special relationship to his God separates him from other people and clearly marks him as the other. ${ }^{20}$

\section{Israelites-Philistines}

Hostility between the nations is a strong motivation for many conflicts in the literary adaptations, thus the aversion to other nations, especially the Philistines, is elaborated.

Next to the portrait of the Philistines as an occupying force many literary works emphasise the emotional distance. This becomes most obvious with the Israelites' view on the Philistines. They are not only the

\footnotetext{
${ }^{19} \mathrm{Cf}$. Gillmayr-Bucher, Richter, 141-150.

${ }^{20}$ The plays of Röttger 1921, Burte 1917 and Eggert 1910 strongly focus on this aspect.
} 
enemy; they are evil or morally inferior in many ways. These evaluations are explicitly expressed: The Philistines are evil from the beginning; they even seduce the 'holy youth' of Israel (Röttger 1921, 3). Sometimes such a pejorative opinion is supported by a Philistine voice. Röttger lets Delilah speak out: 'Ich bin feig wie all mein Volk' (Röttger 1921, 40).

Samson's view on the Philistines often holds xenophobic stereotypes. In Röttgers play Samson shows a very negative attitude towards the Philistines. Insultingly he describes their way of life as: 'lebt schnell und flott, vorne hinein, unten raus, Herz habt ihr dabei nicht nötig' (Röttger $1921,9)$. Samson compares the Philistines to animals and even calls them 'Höllensöhne/Höllenhunde'.

Samson makes insulting remarks on the Philistines in Burte's drama as well. When Burte's Samson utters his impression of the Philistines he associates 'Philisterbraut with Philisterbrut' (Burte 1917, 43). Or he states: 'Schwein und Wein und Weib verschwimmen ineinander' (Burte 1917, 47). This listing contains a climax: from unclean animals for all Israelites-to something a Nazirite may not drink-to a woman: if the woman is included here she becomes part of those forbidden things Samson despises.

The critique on the Philistines is accompanied by Samson's high valuation of his own people and thus further emphasises the difference between the Israelites and the Philistines. Röttger's Samson, for example, admires the balance between words and deeds that characterises the Israelites: 'Denken und Tun stehen in rechtem Maß zueinander' (Röttger 1921, 18).

The consequences from Samson's disdain range between setting clear boundaries and aiming at the Philistines' elimination. Röttger's Samson attempts to distance himself from the Philistines, he does not drink wine or eat meat. He further is portrayed as an arrogant and self confident man. The animosity towards the Philistines may also lead to Samson's wish to destroy them. Burte's Samson makes this very clear: 'entwelten, ganz entarten und vernichten, entgotten' (Burte 1917, 69). Samson wants to alienate the Philistines from the earth, from humankind and from God. Thus he wants to destroy their fundament and push them into otherness and finally into nothingness. Nevertheless, it is not always that simple: Burte's Samson also senses a similarity between himself and the Philistines: 'ihre Besten gleichen mir' (Burte 1917, 73).

As most literary works focus on Samson, a general Philistine view on Israel is rather unusual. Even Wedekind 1914, who restricts his play to a Philistine perspective, does not show their view on Israel. Nevertheless, the 
Philistines' view on Samson usually is quite distinct. He is the enemy or at least 'the other' who poses a threat to the Philistines. He is often portrayed as strong, tyrannic, arrogant and aggressive. Consequently, the one common element almost all literary works resume from the biblical story is the effort of the Philistines to overcome Samson.

Samson's otherness also manifests itself in his appearance. Lembach's play presents Samson as a giant, he is 30 feet tall, and strong as a young bull (Lembach 1911, 136). He is an occupier who not only takes away the Philistines' land but also the hearts of their people (Lembach 1911, 24). Thus Samson is a feared but still an admired enemy. Sometimes the Philistines consider Samson as the best man of the Israelites, he is their strength (Lembach 1911, 14) and the Philistines might even consider him a representative from Israel (Röttger 1921, 13ff). Röttger goes even further and provides the Philistines' estimation of Samson's status of otherness. Compared to his own people Samson appears to be different. He does not fit into the religious tradition of his people and, furthermore, he distances himself from his parents. 'Er ist nicht wie die Juden sonst, die nur mit Beten ins Bett steigen (.. .) er wagt es den Eltern feind zu werden' (Röttger 1921, 9). From a Philistine point of view this makes Samson the other Israelite.

\section{Philistine Women}

Women play a vital role in the relationship between Samson and the Philistines. ${ }^{21}$ Delilah, the most prominent of Samson's adversaries in the biblical story, also stands out in the literary adaptations. In contrast to her biblical portray she is always introduced as a Philistine woman. The modern stories elaborate and unfold her portray as the dangerous foreign woman in great detail. For that purpose, on the one hand, the contrast between Israelite and Philistine women is emphasised and, on the other hand, patriotic ambitions are added to her portrayal.

In Eggert's play the most acrimonious opponent of the Philistine women is Samson's mother. She utters a devastating view on the canaanite women in general: 'Fluch den Weibern Kanaans, die uns die heilige Jugend Israels verführen' (Eggert 1910, 38). Such an image of the seductive canaanite women is contrasted to the image of the innocent and pure Israelite

\footnotetext{
${ }^{21}$ Unlike the biblical text most of the literary adaptations focus only on the relation between Samson and Delilah, whereas Samson's other heroic deeds (Judg 14-15) move to the background. They might be told as an additional anecdote in order to emphasise his strength or his character.
} 
youth. To enhance the image of the foreign temptress literary adaptations sometimes introduce an Israelite woman as Delilah's counterpart.

Even more important than the image of the strange and seductive woman is the tension between patriotism and love. Set in the middle of a national conflict the affection between Samson and Delilah sways between these two attitudes. Delilah, in particular, is torn between loyalty to her people and her love for Samson. Their relationship, however, only emphasises the ethical otherness. From Delilah's point of view Samson's otherness can be expressed admiringly but also in a fearful and accusing way. She compares Samson to an animal, wild and strong: 'Habe mir einen Löwen gefangen' (Röttger 1921, 15) or more fearfully alluding to his supernatural strength she calls him a sorcerer or even a deity (Röttger 1921, 29). Although Delilah is frequently shown to make an effort to bridge the distance and to get rid of Samson's otherness, she fails most of the time. Not only Samson's strength but also his selfishness thwart her approach. Burte lets Delilah shout at Samson: 'Du Ich-Mann du' (Burte 1917, 221).

Samson's relation to women is rather lopsided in most of the literary works. He does not take women seriously but uses them as objects and treats them like simple minded, although sometimes stubborn children. Once he is betrayed, however, he recognises them as a dangerous 'other'. Furious and hurt, Burte's Samson admits this realisation: 'Du stets das andre du (.. .) Du Gegending, du Widermensch, du, du' (Burte 1917, 221).

Yet sometimes the relation between Samson and Delilah is shown as a process. The seemingly insuperable otherness is overcome by Delilah as she distances herself from the Philistines and identifies with Samson, even with his God (e.g. Salten 1928, 78. 177). In this way the tension of otherness is softened by the romantic concept of love. Together Samson and Delilah face the unavoidable end. The novel of Salten even goes one step further and shows Delilah as innocent victim of deceit betrayed by her envious sister.

\section{Samson and His People}

The relation between Samson and his own people reveals yet another facet of his otherness. Like the biblical text the literary images of Samson unfold this aspect.

From the Israelites' point of view Samson appears as a judge and saviour but also as an agitator and thus as a danger for his own people. His ambitions as a freedom fighter are opposed to Israel content with living under a Philistine reign. Consequently the people blame Samson for their woeful situation and do not understand his ambitions (Burte 1917, 60-61). 
They treat him like an untamable animal (Salten 1928, 31; Burte 1917, 84ff) and are eager to deliver Samson into the hands of the Philistines.

Sometimes, however, this general view is differentiated and Samson finds support in his own people. In Eggert's play the disputed attitude towards Samson is exemplarily shown in the different positions of Samson's parents. The mother is presented as the one who knows Samson's secret and who believes in his mission. She calls her son: 'Gott Verlobter' (Eggert 1910, 82). Although she considers Samson's deeds as a result of divine guidance, she, nevertheless, does not approve and tries to lead her son to act in a more traditional way. Samson's father on the other hand strongly disapproves. He accepts the Philistine dominion and thus he requests Samson to accept this situation as well (Salten 1928, 19).

\section{Samson the Man}

Most literary portraits show Samson as superior enemy and also as superior male. His masculinity is a distinctive trait that further marks him as the 'other'. Although Samson's pronounced masculinity distinguishes him from all other males, the difference is especially striking when Samson is compared to the Philistines. Their women admire Samson for his strength, leadership qualities, but also his lenity, his voice and songs. In the eyes of Philistine women Samson has all the qualities Philistine men lack. In their view Samson is the 'true man'. Hence Samson may choose freely among them, as his fellow summarises: 'Alle Frauen stehen ihm offen' (Röttger 1921, 11). Consequently, Samson's masculinity arouses jealousy among Philistine men (Wedekind 1914, 52-53). They also are embarrassed by their failure to capture Samson and thus they fear even more for their reputation in the eyes of their women. In this way shame is revealed as another major theme. The Philistine rulers are embarrassed because they are weak and are not able to protect their people (Salten $1928,102 \mathrm{ff})$.

In Wedekinds play shame and honour become the central topic. The Philistines strive for honour, the rulers as well as Delilah, and constantly fear to be dishonoured. It is obvious that their labile self esteem is closely linked to Samson. Their only hope to find steadiness and honour is based on an eventual triumph over Samson. They cannot gain their honour until Samson looses his (Wedekind 1914, 84ff). Once the Philistines succeed they try to ridicule Samson and thus make him small and harmless: 'Wo lebt ein Tollpatsch, der wie Simson alle Welt zum Lachen bringt (...) kaum sieht man ihn, da platzt man schon vor Lachen' (Wedekind 1914, 84). Violating Samson's honour is amusement for the Philistines: 'entblöß uns deinen 
letzten Rest von Stolz, damit wir, ihn zertrampelnd, uns belustigen' (Wedekind 1914, 89). Nonetheless, the rulers know that Samson distracts the people's mockery from themselves: 'Simson lenkt die Spottlust von uns ab und ewig dankt das Volk für den Spaß' (Wedekind 1914, 84).

Furthermore, Wedekind's drama explicitly connects 'shame and honour' to masculinity: After his defeat Samson considers himself as a woman. From his point of view, his success and superiority, his ability to control the whole situation are constitutive for his masculinity. Once he is blinded he envies Delilah mostly for her ability to take control and to enjoy it: ' $\mathrm{Du}$, die du alles weiterhin überschaust, schwelgst in schamloser Sinnenlust mit mir, wie ich darin mich einst ergötzte ...' (Wedekind 1914, 45) In Samson's self perception gender is reversed: he is the woman, Delilah is the man. 'Durch meine Blindheit sind wir so vertauscht, dass ich das Weib bin, und dass du der Mann bist. Blind weiß ich nicht, wie ich auf andre wirke' (Wedekind 1914, 45). Because his self-confidence is based on the impression he makes on others, he is ashamed as he loses his ability to check this impression: 'Ich schäme mich Delila, wie in der Ehe nur das Weib sich schämt' (Wedekind 1914, 45). From Samson's point of view 'otherness' is swapped.

\section{Samson and His God}

Samson's relation to his God further adds to his otherness. ${ }^{22}$ For Burte the genuine otherness of Samson is closely related to his deity. This relationship singles Samson out. But the close links between Samson and his God are not welcomed by Samson. Rather he agonises over this relationship and his destination, moving between estrangement and closeness to God. Burte's Samson even wants to get rid of God and longs to be just an ordinary man: 'mir graut vor solcher Zwienatur' (Burte 1917, 78). Similarily, Samson opposes to his mission to be a weapon of God in Eggert's drama. He does not want to be reduced to God's tool and shudders to think about God's love. Samson calls it 'fürchterliche Liebe Gottes' (Eggert 1910, 86). Although he senses his secret, he still hopes to be just an ordinary man (Eggert 1910, 125).

In the arguments between Samson and the Philistines Samson's God is sometimes explicitly called the source of Samson's otherness. In Burte's play, for example, a priest of Dagon declares Samson's God as the cause for

\footnotetext{
${ }^{22}$ The literary portrays of Burte 1917, Eggert 1910 and Röttger 1921 emphasise this aspect.
} 
Samson's otherness and subsequently God is also the true enemy of Delilah. She has to separate Samson from his God in order to hold Samson.

Other authors strengthen this relationship further and ascribe Samson a clear mission. In these plays Samson is shown as a freedom fighter, who will liberate Israel with the help of God (e.g. Röttger 1921, Salten 1928). Although Samson agonises with his mission ${ }^{23}$ he finally relates to his destination and his task. ${ }^{24}$ In Salten's novel Samson even wants to become (a saviour) like Moses (Salten 1928, 28ff).

Wedekind also picks up this motive, but he presents it with an ironic trait. After his defeat Samson reflects on his fate: 'mich fruchtlos abzuquälen behagt mir nicht. Dazu ist Simson zu berühmt (...) ist man Gott geweiht, sich abzuschinden?' (Wedekind 1914, 36).

Samson-on the Other Side

In all literary adaptations Samson does not fully belong, neither to his own people nor to the Philistines. Samson remains 'the other', despite his similarities to Philistines and Israelites (Röttger 1921, Burte 1917). One of the reasons for his otherness lies in his own ignorance of boundaries of well established identity and otherness. Because Samson frequently transgresses such boundaries he becomes more and more a lonely hero. His strength, overconfidence and selfishness, his savage behaviour as well as his fondness for Philistine women further contribute to the distance. A priest of Dagon calls Samson: 'entvolkter Mann', a man without people, (Burte 1917, 69) and thus summarises the most important aspect of his otherness.

Samson's equidistance to the Israelites and Philistines is explicitly portrayed in the drama of Röttger. He emphasises the border between the nations as he locates Samson's and Delilah's place of residence there: they live on the border. Samson considers himself as someone, who guards the borderline between Philistines and Israelites: 'Wir wohnen an der Grenze und müssen wachsam sein, denn an der Grenze wachsen die Zwiespalte' (Röttger 1921, 20).

Samson might also be shown as someone who polarises: "An Simson schieden immer sich die Geister', and thus provokes a decision (Burte

\footnotetext{
${ }^{23}$ In Wette's drama the spirits of former judges incriminate Samson in order to emphasise this aspect: 'Du ließest Gott und suchtest dich selbst' (Wette 1904, 26).

24 'Gott sandte mich, dass Israel frei sei' (Röttger 1921, 24).
} 
1917, 202). Although Samson himself does not belong, he makes the differences more obvious.

\subsection{The 'Other' through Millenia}

The scenic composition 'Simson fällt durch Jahrtausende' by Nelly Sachs ${ }^{25}$ unfolds in a prologue and 14 scenic images. ${ }^{26}$ In contrast to the other literary adaptations this composition does not only retell the story of Samson but it tracks Samson's fate on different levels of reality and in different times. The connection with the biblical text is established in the prologue retelling the biblical story of the overwhelming of Samson (Judg 16). Delilah cuts Samson's hair and bereaves him of his strength and his unity with God.

Subsequently the first scene shows that the story of Samson and Delilah is to be continued. In an abstract space the figures of the prologue reflect the events and their deeds, their intention and the results they gained. The following scenic images are performed on different levels of reality. The story in the foreground (the scenic images $2,4,5,6,7,8,11$, 12) shows the everyday life of Manes, a school custodian, and his wife Nina in the 20th century while the other scenic images $(3,9,10,13,14)$ offer an abstract reflection or show imaginary worlds.

The plot of the story of Nina and Manes can be summarised as follows: Manes is a big, strong man, a hero who saved 37 children from a burning school building. Ever since he suffers from 'falling sickness', an absence of mind, when he remembers an undefined past. This sickness makes it difficult for Manes to cope with everyday life and, furthermore, it makes him unpredictable. He is considered peculiar, even dangerous. More and more Manes becomes an outsider. Meanwhile his wife Nina tries to escape from her life with Manes with the help of her lover Werach, a schoolteacher. He supports Nina when she hospitalises her husband Manes. Nevertheless, Nina's hopes do not come true.

\footnotetext{
${ }^{25}$ Nelly Sachs, a Jewish-German poet, portrays the fate of her Samson after the Shoah. Although the horror of these years is not explicitly referred to in this adaptation, Samson, nevertheless, shows traces of a 'jewish fate' that roots in the biblical past and marks him as 'the other'.

${ }^{26}$ This short play is written in the poetic language of Nelly Sachs, using her dense, almost hermetically sealed, metaphorical language. And it offers a vast amount of allusions, connections and references between the scenic images, to other poems of Nelly Sachs and to the biblical texts.
} 
The otherness of Manes/Samson forms the centre of the play. From every point of view he remains 'the other'. His disease separates him from the people around him and carries him away into a world only he has access to (Sachs 1962, 208).

Ich bin gesund; Herr Rektor,

nur daß ich manches Mal mehr sehe als andere Leute.

Die Wände der Nacht weichen zurück-und dann-

höre ich wie dieser Stern sich mit Musik dreht-

The other world he sees in his absences offers glimpses of an alter ego. With numerous allusions the readers, little by little, become aware that Manes continues Samson's fate. The secret Manes is eager to keep emerges as his biblical past (Sachs 1962, 206).

Die Zunge wieder gebissen,

damit kein Wort entschlüpft. Großes Geheimnis.

Nahe war ich bei dir-so nahe-

Habe meinen anderen Leib geschaut

aus Fäden gesponnen-Lebensspeichel-

nicht mehr zurückkehren in die Menschennacht

nein-nicht zu der Frau-nicht zu den Händen

die töten-zu der Sprache, die Herzen blutig reißt-

Nina, however, does not understand Manes and his disease. His otherness disturbs her (Sachs 1962, 201-202).

Wenn's doch eine andere Krankheit wäre,

so eine reelle-Lungen-Nieren-Herz-Blinddarm, das

ist zu operieren-

aber Fallsucht-

da ist keine Ordnung drin

Nicht herausfallen

Nevertheless, her seemingly ignorant chatter links her to Delilah (Sachs 1962, 202).

Ach mein Himmel, er ist auf der Treppe

knistert mit dem Blumenpapier-

und der Andere

fällt-fällt wohin-ha in die Liebe

While Nina waits for her lover, she hears him coming with a gift, she thinks about Manes and mocks his disease. In her point of view the love, wherein Manes falls, is rediculous. 
Werach, Ninas lover, fears Manes, he sees him as a giant with enormous strengths, however, out of time and thus comes quite close to the central point of the play. Only in such short glimpses do the figures sense the history of Manes/Samson and recognise his otherness as being lost in millenia (Sachs 1962, 204).

Unzeitgemäß dieser Vorzeitriese

Weiß mit seiner Kraft nicht mehr wohin-schlägt rauchend aus seinem Gehirn-

But not only Nina and her lover consider Manes as 'the other', also his employer, the school principal, tries to classify him similarly (Sachs 1962).

Ja solche Leute gibt es-hat es immer gegeben.

Aber schade um Ihren kraftvollen Körper

der anderen Dienst auf Erden tun könnte

Man sah ja was er leisten konnte unter der Feuersbrunst

Immer durch die Flammen-und wieder durch die Flammen-

Ein ganzes Heer von Helden steckt in diesem Körper

Manes, however, tries to fit in, to overcome his otherness and to gain some affection. He even goes to the barber and has his hair cut. Although the monologue resembles a stereotyped chitchat, the barber's talk links the situation to the biblical story. The motif of Samson's hair is linked to Manes' last effort to get rid of his otherness (Sachs 1962, 210).

Haare schneiden, Herr Manes

Bart gut einseifen-so wird man Mensch

Sonst ist's aus mit der Frauenliebe

Haar weg-Bart weg-aber dafür kommt die Liebe zurück ...

da heißt es angleichen-angleichen-Barttracht

nur nicht herausfallen-nur nicht Tag spielen wenn es Nacht ist

The barber supports Manes' effort, but he does not understand his self dedication (Sachs 1962, 211).

Was reden Sie da-Ihre Stimme klingt so schwach

Wenn ich recht verstehe wollen Sie Ihrer Frau die abgeschnittenen Haare schenken-

Nina, however, rejects Manes' last desperate attempt to please and to fit in. Thus Manes' surrender is worth nothing. 
In Sachs's scenic play Manes cannot overcome his otherness, nor is he able to find a positive way to deal with it. There is no goal to be reached, rather, all Manes has achieved lies in the past. Thus his otherness is something he has to endure. Unlike the other literary adaptations of the Samson story, the otherness of Manes makes him more sensitive and anticipating. He is able to see more than one level of reality but this knowledge and subsequently his different point of view marks him as 'the other'. He does not fit into a one-dimensional reality.

Manes continues the story of the biblical Samson. In contrast to the literary portrayals of the beginning of the century Samson/Manes has no chance to win. His fate has already been sealed and can only be 'durchschmerzt' (Sachs 1962, 236). Thus it is the defeated hero that lives on.

Manes is inscribed into the story and fate of Samson as he continues his otherness. His otherness is all that remains.

\section{The Mirror of Otherness}

In the literary adaptations of the biblical story the various aspects of Samson's otherness seem to be one of the most attractive traits. As the biblical story only sets up a frame, Samson cannot be reduced to fit one particular scheme, he rather fits many. Using the biblical story as a model thus offers various possibilities to shape the story according to a contemporary version of otherness. Set off into the past, Samson's conflicts offer a mirror for actual disputes. As a biblical figure, however, Samson offers more. His story claims to reveal basic principles, or as in Wedekind's play, to mock them.

Samson's story is a continuous story of otherness. His portrait remains in between shame and honour, duty and emotion, patriotism and love and, subsequently, also between fool and hero.

While Samson's otherness unfolds and the audience watches his transgressions, their own images of cultural borders are challenged. Samson puts the concepts of identity and otherness on. Thus Samson is a tool not only in the hands of God but also of the author to address his or her question of 'otherness'.

\section{Bibliography}

Alter, R., 'Samson without folklore', in: S. Niditch (ed.), Text and tradition: The Hebrew Bible and Folklore (The Society of Biblical Literature. Semeia studies), 47-56, Atlanta 1990.

Amit, Y., The book of Judges: The Art of Editing, Leiden-Boston-Köln 1999. 
Bakhtin, M., Probleme der Poetik Dostoevskijs (trans. A. Schramm), Frankfurt 1985.

Bynum, D. E., 'Samson as a biblical Phär Oreskwos', in: S. Niditch (ed.), Text and tradition: The Hebrew Bible and Folklore (The Society of Biblical Literature. Semeia studies), 57-73, Atlanta 1990.

Camp, C. V., 'Riddlers, tricksters and strange women in the Samson story', in: C. Camp, Wise, strange and holy: The strange woman and the making of the Bible (JSOT.s 320), 94-143, Sheffield 2000.

Clines, D. J., 'David the man. the construction of masculinity in the Hebrew Bible', in: D. Clines, Interested parties: The ideology of writers and readers of the Hebrew Bible (JSOT.s 205), 212-243, sheffield 1995.

Exum, J. C., 1983, 'The theological dimensions of the Samson saga', VT 32: 30-45.

--, 1990, 'The centre cannot hold: Thematic and textual instabilities in judges', CBQ 52: 410-431.

--, Fragmented women: Feminist (sub)versions of biblical narratives (JSOT.s 163), Sheffield 1993.

--, Plotted, shot, and painted: Cultural representations of biblical women (JSOT.s 215), Sheffield 1996.

Gillmayr-Bucher, S. 'Die Richter', in: H. Schmidinger (ed.). Die Bibel in der deutschsprachi-gen Literatur des 20. Jahrhunderts. Bd. 2 Personen und Figuren. Mainz 1999, 137-150.

--, Erzählte Welten im Richterbuch: Narratologische Aspekte eines polyfonen Diskurses (BINS 116), Brill 2013.

Greenstein, E., 1981, 'The riddle of Samson', Prooftexts 1: 237-260.

Jonker, L. C., 1992, 'Samson in double vision: Judges 13-16 from historical-critical and narrative perspectives', JNSL 18: 49-66.

Kegler, J., 'Simson-Widerstandskämpfer und Volksheld', in: G. Freund \& E. Stegemann (eds.), Theologische Brosamen für Lothar Steiger (DBBAT Beiheft 5), 233-255, Heidelberg 1985.

Niditch, S., 1990, 'Samson as culture hero, trickster, and bandit: The empowerment of the weak', CBQ 52: 608-624.

Van Wolde, E., 2008, 'Sentiments as Culturally Constructed Emotions: Anger and Love in the Hebrew Bible', BI 16: 1-24.

Waldenfels, B., Topographie des Fremden: Studien zur Phänomenologie des Fremden, Frankfurt 1997.

Weizman, S., 2002, 'The Samson story as border fiction', BI 10: 158-174.

\section{Literary Adaptations of the Samson Story}

Burte, H., Simson: Ein Schauspiel, Leipzig 1917.

Eggert, E., Simson: Tragödie in fünf Aufzügen, Ravensburg 1910.

Lembach, A., Samson: Ein Drama in vier Akten, Berlin 1911.

Röttger, K., Simson: Ein Drama, Leipzig 1921.

Sachs, N., 'Simson fällt durch Jahrtausende', in: N. Sachs, Zeichen im Sand: Die szenischen Dichtungen der Nelly Sachs, 185-238, Frankfurt 1962.

Salten, F., Das Schicksal eines Erwählten: Roman, Berlin 1928.

Wedekind, F., Simson oder Scham und Eifersucht: Dramatisches Gedicht in 3 Akten, München 1914.

Wette, H., Simson: Tragödie in fünf Akten: Nach den Worten des Alten Testaments, Leipzig 1904. 